Original Article

\title{
STUDY ON CAUSE-EFFECT RELATIONS AND OPTIMIZATION OF TABLETS CONTAINING AQUILARIA CRASSNA SPRAY-DRIED EXTRACT
}

\section{BUI THI THU HUONG ${ }^{1}$, BOONYAPHAT MONSATTA², NGUYEN DUC HANH ${ }^{1 *}$, PHAN HOANG DOAN PHUONG1, DO QUANG DUONG1}

${ }^{1}$ Faculty of Pharmacy, University of Medicine and Pharmacy at Ho Chi Minh City, Vietnam, ${ }^{2}$ Faculty of Pharmacy, Mahidol University, Thailand

Email: duchanh@ump.edu.vn

Received: 04 Jul 2017 Revised and Accepted: 31 Aug 2017

\section{ABSTRACT}

Objective: The aim of this study was to develop and optimize the formulation of tablets containing Aquilaria crassna extract using the direct compression method.

Methods: D-optimal design based on three independent variables was applied to evaluate the cause-effect relations and optimize the $A$. crassna tablet formulation. The weight variation $\left(\mathrm{Y}_{1}\right)$, disintegration time $\left(\mathrm{Y}_{2}\right)$, hardness $\left(\mathrm{Y}_{3}\right)$ and friability $\left(\mathrm{Y}_{4}\right)$ were investigated with respect to three independent variables including \% dicalcium phosphate anhydrous (DCPA) in filler $\left(\mathrm{X}_{1}\right), \%$ filler $\left(\mathrm{X}_{2}\right)$ and \% croscarmellose sodium (CCNa) ( $\left.\mathrm{X}_{3}\right)$. The dissolution study of the optimized $A$. crassna tablets were investigated in simulated gastric fluid (SGF) (pH 1.2) using a validated high-performance liquid chromatography (HPLC) method for mangiferin analysis.

Results: All investigation factors were found to have significant effects on the physical properties of $A$. crassna tablet. The tablet hardness and the disintegration time increased in positive relations with the ratios of DCPA. The results exhibited the negative relations between disintegration time and the percentages of CCNa. The optimized A. crassna tablet formulation which included $35 \%$ (w/w) DCPA in filler, $60 \%$ (w/w) filler and 7\% $(\mathrm{w} / \mathrm{w})$ CCNa possessed the weight variation of $1.38 \%(\mathrm{w} / \mathrm{w})$, the disintegration time of 6.29 min, the hardness of $85.63 \mathrm{~N}$ and the friability of 0.41 $\%(\mathrm{w} / \mathrm{w})$. The optimized $A$. crassna tablet formulation was experimentally examined which demonstrated a good agreement between the experimental and predicted values. Mangiferin was found to release completely from the optimized $A$. crassna tablets within 30 min.

Conclusion: The cause-effect relations and optimization of $A$. crassna tablet formulation were investigated and reported for the first time. The $A$. crassna spray-dried extract could be formulated into tablet by direct compression method with good mechanical properties and acceptable release profile.

Keywords: Aquilaria crassna, Spray-dried extract, Direct compression, Optimization, Herbal formulation, Oral tablet

(C) 2017 The Authors. Published by Innovare Academic Sciences Pvt Ltd. This is an open access article under the CC BY license (http://creativecommons.org/licenses/by/4.0/) DOI: http://dx.doi.org/10.22159/ijpps.2017v9i10.21117

\section{INTRODUCTION}

Aquilaria crassna has been traditionally used in Asia countries for the production of incense, perfumes and traditional medicines [1]. The leaves of $A$. crassna have been reported to possess antipyretic, analgesic, laxative and antimicrobial activities [2]. The daily recommended dose of $A$. crassna leave extract ranges from $300 \mathrm{mg}$ to $600 \mathrm{mg}$ as traditional use in Vietnam. Mangiferin (fig. 1) is one of the active xanthone components of $A$. crassna leaves [3, 4]. Mangiferin has been reported to exhibit antioxidant, anti-diabetic, anti-hyperuricemic, antiviral, anticancer and anti-inflammatory activities $[5,6]$.

Direct compression is the simplest and most cost-effective tablet manufacturing technique by which the tablets are directly compressed from a blend of ingredients without a preliminary granulation or agglomeration process $[7,8]$. Despite only a few steps in the manufacturing process, the product design in direct compression can be challenged due to some competing objectives [9]. The use of poorly controlled or inadequately specified raw materials may lead to the poor flowability of the powder and inconsistent tablet weight, the lack of content uniformity, unsatisfactory tablet strength or segregation and dissolution failure $[10,11]$. A. crassna spray-dried extract is an active ingredient possesses the poor flowability property which needs to be overcome while preparing $A$. crassna tablets by direct compression method. In this study, the fillers were added into the formulation to improve the flowability of $A$. crassna spray-dried extract so that $A$. crassna tablets could be produced by direct compression method.

The aim of this study was to investigate the cause-effect relations between independent variables (\% DCPA in filler, \% filler and \% $\mathrm{CCNa}$ ) and dependent variables (weight variation, disintegration time, hardness and friability of $A$. crassna tablet) and optimize the formulation of $A$. crassna tablet from $A$. crassna spray-dried extract for oral administration using direct compression method.<smiles>O=c1c2cc(O)c(O)cc2oc2cc(O)c([C@H]3O[C@H](CO)[C@@H](O)[C@H](O)[C@H]3O)c(O)c12</smiles>

Fig. 1: Chemical structure of mangiferin

\section{MATERIALS AND METHODS}

\section{Materials}

A. crassna spray-dried extract was a gift from Evergreen Forest JSC (Vietnam). Silicified microcrystalline cellulose (SMCC) (Prosolv ${ }^{\circledR}$ SMCC 90) and croscarmellose sodium (Vivasol ${ }^{\circledR}$ ) were received from JRS Pharma (Germany) via Sapharchem Co., Ltd (Vietnam). Magnesium stearate was a gift from Brenntag (Denmark). Dicalcium phosphate anhydrous $\left(\mathrm{A}-\mathrm{Tab}^{\circledR}\right)$ was received from Innophos (Chicago Heights, IL, USA) via Asia Shine Trading and Service Co. Ltd. (Vietnam).

\section{Morphology of $\boldsymbol{A}$. crassna spray-dried extract}

The shape and size of $A$. crassna spray-dried extract were investigated by scanning electron microscope (SEM) (JSM-IT100, 
JEOL, Tokyo, Japan). The sample was mounted on a SEM stub using double-sided adhesive tape and then sputter-coated with gold particles [12]. SEM micrograph of A. crassna spray-dried extract was then photographed.

\section{Preparation of tablets}

A direct compression method was used for the preparation of tablet formulations. Ingredients were weighed and pass through 40 mesh sieve. Powder blends of all formulations were mixed by tumbling action and then compressed using a single punch tableting machine (Riva Minipress MII, Riva, Germany) with a concave punch of $11 \mathrm{~mm}$ diameter.

\section{Experimental design and data analysis}

The constituents of the tablet formulations included A. crassna spray-dried extract as active compounds, mixtures of DCPA and SMCC as the filler, CCNa as the supper disintegrant and magnesium stearate $(1 \%)$ as lubricant

A total of 14 experimental runs according to the D-optimal design were generated by Design Expert software (version 6.0.6, Stat-Ease Inc., Minneapolis, USA) to study the effects of independent variables on dependent variables. Percentages of DCPA in filler $\left(\mathrm{X}_{1}\right), \%$ filler $\left(\mathrm{X}_{2}\right)$ and \% croscarmellose sodium $\left(\mathrm{X}_{3}\right)$ were selected as three independent variables whereas weight variation $\left(\mathrm{Y}_{1}\right)$, disintegration time $\left(\mathrm{Y}_{2}\right)$, hardness $\left(\mathrm{Y}_{3}\right)$ and friability $\left(\mathrm{Y}_{4}\right)$ were chosen as four dependent variables. Percentage of DCPA in filler $\left(\mathrm{X}_{1}\right)$ and \% CCNa $\left(\mathrm{X}_{3}\right)$ were studied at three levels and \% filler $\left(\mathrm{X}_{2}\right)$ was studied at two levels (table 1). The experimental range for each independent variable was selected based on the results of initial trials. The compositions of 14 formulations are given in table 2. All formulations were conducted in triplicate and data were exhibited as mean \pm standard deviation.

The results of experimental design were analyzed using BCPharSoft OPT software (Vietnam). The best fitting model was chosen. In order to achieve a better understanding of the cause-effect relations between the independent and dependent variables, the 3D diagrams of the fitted models were depicted. D-optimal design employed for the study is shown in table 2 .

The optimized formulation was performed in triplicate for further validation. The observed response data of the optimized formulation were compared with their predicted data created by BCPharSoft OPT software using SPSS version 20.0 (SPSS, Inc., Chicago, IL, USA).

Table 1: Variables in experimental design

\begin{tabular}{|c|c|c|c|}
\hline & \multicolumn{3}{|c|}{ Levels } \\
\hline & Low & Medium & High \\
\hline \multicolumn{4}{|l|}{ Independent variables } \\
\hline $\mathrm{X}_{1}: \%$ DCPA in filler $(\mathrm{w} / \mathrm{w})$ & 10 & 30 & 50 \\
\hline $\mathrm{X}_{2}: \%$ filler $(\mathrm{w} / \mathrm{w})$ & 40 & 60 & \\
\hline $\mathrm{X}_{3}: \% \mathrm{CCNa}(\mathrm{w} / \mathrm{w})$ & 0 & 4 & 8 \\
\hline Dependent variables & \multicolumn{3}{|c|}{ Constraints } \\
\hline $\mathrm{Y}_{1}$ : weight variation $(\%, \mathrm{w} / \mathrm{w})$ & \multicolumn{3}{|c|}{ Minimum } \\
\hline $\mathrm{Y}_{2}$ : disintegration time (min) & \multicolumn{3}{|c|}{ Minimum } \\
\hline $\mathrm{Y}_{3}:$ hardness $(\mathrm{N})$ & \multicolumn{3}{|c|}{ Maximum } \\
\hline$Y_{4}:$ friability $(\%, w / w)$ & \multicolumn{3}{|c|}{ Minimum } \\
\hline
\end{tabular}

\section{Uniformity of tablet weight}

Twenty tablets from each batch were selected at random and weighed individually using a digital analytical balance (XB 220A; Precisa, Dietikon, Switzerland). The average weight of the tablets was then determined. Percentage deviation of each individual tablet from the average weight was calculated.

\section{Disintegration test}

The disintegration tests were performed according to the British Pharmacopoeia [13]. Six tablets were separately placed into the basket rack assembly of a disintegration test apparatus (ZT 501, Erweka, Germany). The tablets were immersed into $800 \mathrm{ml}$ distilled water maintained at $37 \pm 2{ }^{\circ} \mathrm{C}$. The time was recorded when each tablet completely disintegrated with no residue remaining. The results were recorded as the mean \pm standard deviation.

\section{Hardness test}

The hardness test was carried out using a hardness tester (TBH 210, Erweka, Germany). Ten tablets from each batch were selected at random. Each tablet was placed between the jaws of the hardness tester and force was applied until the tablet broken. The average hardness \pm standard deviation was calculated.

\section{Friability test}

Friability test was performed according to the British Pharmacopoeia [12] using a friability tester (Model: TA3B, Erweka, Germany). The drum was rotated at $25 \mathrm{rpm}$ for $4 \mathrm{~min}$. The tablets were dedusted and weighed before and after using the tester. The percentage friability was calculated using the following equation.

$$
\% \text { Friability }=\frac{W_{1}-W_{2}}{W_{1}} \times 100
$$

Where $W_{1}$ and $W_{2}$ are the initial and final weights of all tablets, respectively.

\section{Dissolution study}

The dissolution study of the optimized $A$. crassna tablet was carried out using a dissolution apparatus (Erweka DT 700, Germany). Dissolution was conducted in $900 \mathrm{ml}$ of simulated gastric fluid without enzyme (SGF) at a temperature of $37 \pm 0.5^{\circ} \mathrm{C}$ and a paddle speed of $100 \mathrm{rpm}$. At the predetermined time intervals $0,5,10,15$, 20 and $30 \mathrm{~min}, 5 \mathrm{ml}$ of release medium were withdrawn and replaced each time with $5 \mathrm{ml}$ of fresh medium. Mangiferin concentrations in the samples were determined by a validated HPLC method.

\section{Analytical method of mangiferin}

Mangiferin was analyzed by an Azura HPLC system (Knauer, Germany). The separation was performed on a Syncronis C18 column $(250 \times 4.6 \mathrm{~mm} ; 5 \mu \mathrm{m})$ (Thermo Scientific, USA). Mobile phase was mixtures of acetonitrile and $0.2 \%$ acetic acid in water with a gradient program. The ratios of acetonitrile were $8 \%, 12 \%$, $25 \%$ and $50 \%$ at $0 \mathrm{~min}, 12 \mathrm{~min}, 30 \mathrm{~min}$ and $35 \mathrm{~min}$, respectively. The flow rate was set at $1 \mathrm{ml} / \mathrm{min}$. Detection was performed at a wavelength of $330 \mathrm{~nm}$ at $30^{\circ} \mathrm{C}$. The sample injection volume was 20 $\mu$ l. The HPLC analytical method was validated according to the International conference on harmonization (ICH) guidelines on system suitability, specificity, linearity, precision and accuracy.

\section{RESULTS AND DISCUSSION}

\section{Physicochemical properties of $A$. crassna spray-dried extract}

Morphology of A. crassna spray-dried extract is shown in fig. 2. SEM image revealed that $A$. crassna spray-dried extract particles had nearly spherical shape with the average diameter of less than $30 \mu \mathrm{m}$. 
As the general guide, the maximum angles of repose of powder close to $25^{\circ}$ correspond to excellent flow properties. A. crassna spraydried extract powder with an angle of repose greater than $45^{\circ}$ was found to possess a very poor flowability in spite of their spherical shape. This phenomenon can be explained by the cohesiveness of the small particles of $A$. crassna spray-dried extract powder due to the electrostatic charge interactions [14].

\section{Optimization data analysis and validation of optimization} model

The values of independent variables and their responses of 14 formulations generated by Design Expert software are shown in table 2. The ranges of weight variation $\left(\mathrm{Y}_{1}\right)$, disintegration time $\left(\mathrm{Y}_{2}\right)$, hardness $\left(\mathrm{Y}_{3}\right)$ and friability $\left(\mathrm{Y}_{4}\right)$ were found to be $0.74-3.39 \%, 4.00$ $18.45 \mathrm{~min}, 24-116 \mathrm{~N}$ and $0.04-16.25 \%$, respectively.

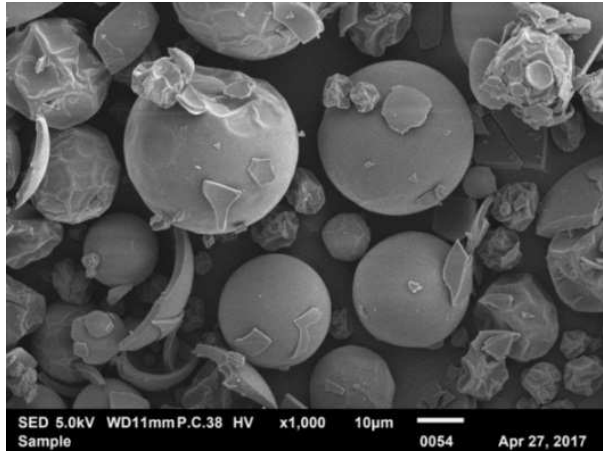

Fig. 2: SEM image of A. crassna spray-dried extract powder

Table 2: The independent variables of 14 formulations (F1-F14) and their responses

\begin{tabular}{|c|c|c|c|c|c|c|c|}
\hline \multirow[t]{2}{*}{ Formulation } & \multicolumn{3}{|c|}{ Independent variables } & \multicolumn{4}{|c|}{ Dependent variables } \\
\hline & $\mathrm{X}_{1}(\%)$ & $\mathrm{X}_{2}(\%)$ & $\mathrm{X}_{3}(\%)$ & $Y_{1}(\%)$ & $Y_{2}(\min )$ & $Y_{3}(N)$ & $Y_{4}(\%)$ \\
\hline F1 & 10 & 40 & 4 & $1.85 \pm 0.11$ & $9.09 \pm 3.04$ & $45.87 \pm 9.79$ & $1.48 \pm 0.37$ \\
\hline $\mathrm{F} 2$ & 30 & 40 & 8 & $1.75 \pm 0.10$ & $8.54 \pm 2.64$ & $49.53 \pm 8.21$ & $1.34 \pm 0.84$ \\
\hline F3 & 30 & 60 & 8 & $1.10 \pm 0.43$ & $5.84 \pm 0.21$ & $86.37 \pm 9.35$ & $0.75 \pm 0.21$ \\
\hline F4 & 50 & 40 & 8 & $2.87 \pm 0.18$ & $7.80 \pm 1.90$ & $54.27 \pm 11.65$ & $1.32 \pm 1.16$ \\
\hline F5 & 50 & 60 & 8 & $1.37 \pm 0.46$ & $7.31 \pm 1.23$ & $95.53 \pm 9.12$ & $0.55 \pm 0.52$ \\
\hline F6 & 30 & 60 & 0 & $1.68 \pm 0.14$ & $15.71 \pm 1.45$ & $84.63 \pm 7.80$ & $0.55 \pm 0.18$ \\
\hline F7 & 10 & 40 & 8 & $2.85 \pm 0.66$ & $8.63 \pm 2.02$ & $44.80 \pm 7.95$ & $1.27 \pm 0.83$ \\
\hline F8 & 10 & 40 & 0 & $1.47 \pm 0.21$ & $10.60 \pm 3.11$ & $44.50 \pm 9.72$ & $1.19 \pm 0.72$ \\
\hline F9 & 30 & 40 & 4 & $2.54 \pm 0.48$ & $10.46 \pm 2.27$ & $48.60 \pm 8.98$ & $1.56 \pm 1.31$ \\
\hline F10 & 10 & 60 & 0 & $1.58 \pm 0.24$ & $11.98 \pm 5.79$ & $74.37 \pm 15.79$ & $0.75 \pm 0.74$ \\
\hline F11 & 30 & 40 & 0 & $2.99 \pm 0.26$ & $9.64 \pm 1.04$ & $47.50 \pm 5.09$ & $1.17 \pm 0.64$ \\
\hline F12 & 10 & 60 & 4 & $1.51 \pm 0.60$ & $6.98 \pm 2.24$ & $80.07 \pm 7.40$ & $0.46 \pm 0.18$ \\
\hline F13 & 50 & 60 & 4 & $1.55 \pm 0.34$ & $8.01 \pm 0.67$ & $93.97 \pm 13.51$ & $0.61 \pm 0.25$ \\
\hline F14 & 50 & 60 & 0 & $1.58 \pm 0.18$ & $15.82 \pm 3.03$ & $96.03 \pm 8.24$ & $0.71 \pm 0.11$ \\
\hline
\end{tabular}

$\mathrm{X}_{1}$ (\% DCPA in filler); $\mathrm{X}_{2}\left(\%\right.$ filler); $\mathrm{X}_{3}\left(\% \mathrm{CCNa}\right.$ ); $\mathrm{Y}_{1}$ (weight variation, \%); $\mathrm{Y}_{2}$ (disintegration time, min); $\mathrm{Y}_{3}$ (hardness, $\mathrm{N}$ ); $\mathrm{Y}_{4}$ (friability,\%). Values are expressed as mean $\pm \mathrm{SD}(\mathrm{n}=3)$

The data in table 2 were used as inputs for BCPharSoft OPT to study on the cause-effect relations and optimize the $A$. crassna tablet formulation.

Training parameters were set at:

-Test groups: $\mathrm{Y}_{1}[9,13], \mathrm{Y}_{2}[6,12], \mathrm{Y}_{3}[5,7], \mathrm{Y}_{4}[2,13]$
-Transfer function: Back Propagation Learning

The three-dimensional (3D) response surface plots were used to study the interaction effects of two independent variables on the dependent variables at one time, when the third variable was kept at a constant level.

Table 3: Model statistics from BC phar soft OPT outputs

\begin{tabular}{lll}
\hline Dependent variables & $\mathbf{R}^{\mathbf{2}}$ training & $\mathbf{R}^{\mathbf{2}}$ test \\
\hline $\mathrm{Y}_{1}$ : weight variation (\%) & 1.00 & 0.99 \\
$\mathrm{Y}_{2}$ : disintegration time (min) & 0.99 \\
$\mathrm{Y}_{3}$ : hardness (N) & 0.99 & 0.99 \\
$\mathrm{Y}_{4}$ : friability (\%) & 1.00 & 0.99 \\
\hline
\end{tabular}

All $\mathrm{R}^{2}$ values which were found to be more than 0.9 indicated a very good reliability of the models (table 3 ). Therefore, these models could be used for multivariate optimization.
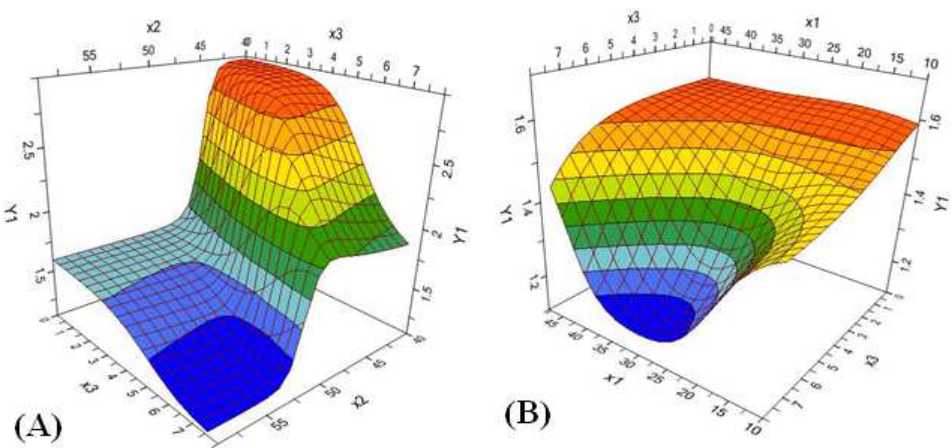

Fig. 3: Response surface plots showing the effect of $(A) \%$ filler $\left(X_{2}\right)$ and \% CCNa $\left(X_{3}\right)$ on weight variation $\left(\mathrm{Y}_{1}\right)$; $(\mathrm{B}) \%$ DCPA in filler $\left(\mathrm{X}_{1}\right)$ and $\% \mathrm{CCNa}\left(\mathrm{X}_{3}\right)$ on weight variation $\left(\mathrm{Y}_{1}\right)(\mathrm{n}=3)$ 


\section{Effect of variables on weight variation}

The weight variations of 14 formulations (between $0.74 \%$ and $3.39 \%$, $\mathrm{w} / \mathrm{w}$ ) were found to be within the acceptable limits (not more than 5 $\%, w / w)$ (table 2). Weight variation $\left(\mathrm{Y}_{1}\right)$ demonstrated the negative relationship with \% filler $\left(\mathrm{X}_{2}\right)$. It is evident from fig. 3 that weight variation $\left(\mathrm{Y}_{1}\right)$ decreased with increasing \% filler $\left(\mathrm{X}_{2}\right)$. Percentage of filler played an important role in determining the weight variation. When \% filler increased, the electrostatic charges of the powder mixture reduced and the cohesiveness decreased, hence the flowability of the powder mixture was improved. This relation was in accordance with the rule reported previously by Bushra $\mathrm{R}$ [15].

Weight variation $\left(\mathrm{Y}_{1}\right)$ was found to be high at the low and high level of $\%$ DCPA in filler $\left(\mathrm{X}_{1}\right)$. However, at the medium level of \% DCPA in filler $\left(\mathrm{X}_{1}\right)$ the weight variation decreased significantly (fig. 3B). It can be explained by the high density of DCPA. The separation of the powder mixture may occur at low and high level of \% DCPA in filler $\left(\mathrm{X}_{1}\right)$.

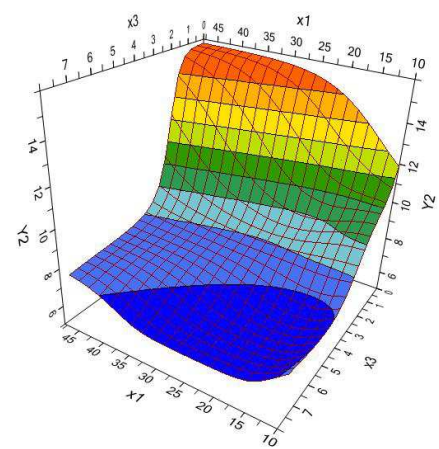

Fig. 4: Response surface plots showing the effect of \% DCPA in filler $\left(X_{1}\right)$ and \% CCNa $\left(X_{3}\right)$ on disintegration time $\left(Y_{2}\right)(n=3)$

\section{Effect of variables on disintegration time}

Disintegration data showed that all tablets of 14 formulations could be disintegrated completely within $20 \mathrm{~min}$. It can be seen from fig. 4 that when \% $\mathrm{CCNa}\left(\mathrm{X}_{3}\right)$ increased, disintegration time $\left(\mathrm{Y}_{2}\right)$ significantly reduced. This relation could be explained due to the fact that $\mathrm{CCNa}$ is a supper disintegrant. CCNa could increase the hydrostatic pressure acting either via swelling or by water wicking, or by combination of these mechanisms [16]. Therefore, the disintegration of A. crassna tablets could be improved when CCNa was added.

Moreover, at a certain level of \% CCNa $\left(\mathrm{X}_{3}\right)$, when \% DCPA in filler $\left(\mathrm{X}_{1}\right)$ increased, disintegration time $\left(\mathrm{Y}_{2}\right)$ increased. DCPA is a nonhygroscopic filler and absorbed less than $1 \%$ water [17], therefore, when $\%$ DCPA in filler $\left(\mathrm{X}_{1}\right)$ increased, the water penetration into the tablet may be slowed down and hence, the disintegration process was prolonged. This was in line with the rule reported previously by Tibalinda P [18].

\section{Effect of variables on hardness}

Hardness data in table 2 shows that all formulations with $40 \%$ filler (F1, F2, F4, F7, F8, F9 and F11) possessed low hardness compared to the other formulations with $60 \%$ filler $\left(\mathrm{X}_{2}\right)$.

Fig. $5 \mathrm{~A}$ shows that when $\%$ filler $\left(\mathrm{X}_{2}\right)$ increased, the hardness $\left(\mathrm{Y}_{3}\right)$ significantly increased. The mixtures of DCPA and SMCC as fillers were found to be able to improve the hardness of $A$. crassna tablet. Moreover, fig. 5B shows that at a certain level of $\%$ filler $\left(\mathrm{X}_{2}\right)$, the hardness $\left(\mathrm{Y}_{3}\right)$ significantly increased when \% DCPA in filler $\left(\mathrm{X}_{1}\right)$ increased. DCPA is a brittle inorganic excipient therefore it could support the compaction process $[19,20]$. SMCC which composed of $98 \%$ microcrystalline cellulose had advantages in compressibility of microcrystalline cellulose. As a result, SMCC could improve the hardness of the A. crassna tablet [21]. Similar results were previously reported by Solaiman A [22, 23].
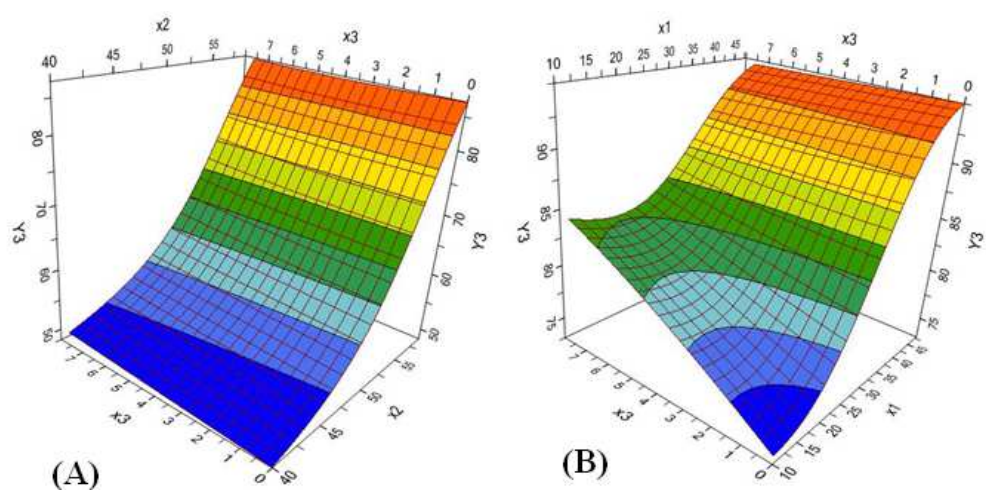

Fig. 5: Response surface plots showing the effect of $(A) \%$ filler $\left(\mathrm{X}_{2}\right)$ and \% CCNa $\left(\mathrm{X}_{3}\right)$ on hardness $\left(\mathrm{Y}_{3}\right) ;(\mathrm{B}) \%$ DCPA in filler $\left(\mathrm{X}_{1}\right)$ and \% CCNa $\left(X_{3}\right)$ on hardness $\left(Y_{3}\right)(n=3)$
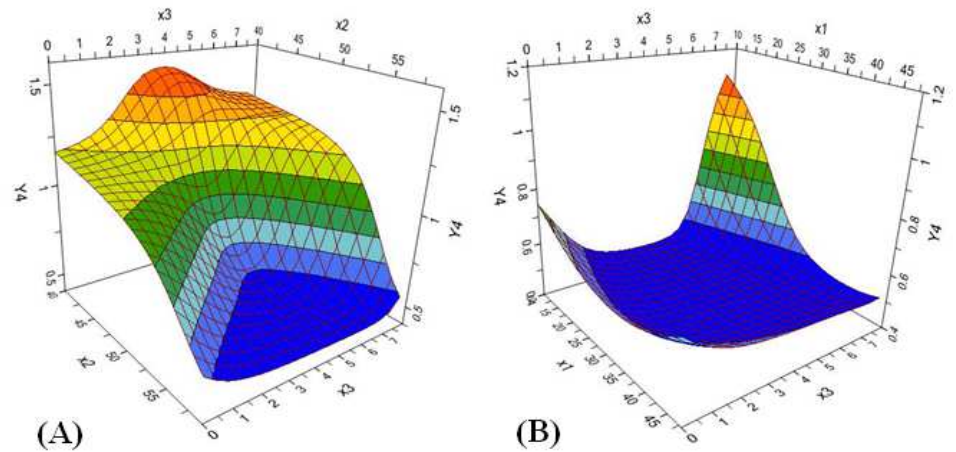

Fig. 6: Response surface plots showing the effect of $(A) \%$ filler $\left(\mathrm{X}_{2}\right)$ and \% CCNa $\left(\mathrm{X}_{3}\right)$ on friability $\left(\mathrm{Y}_{4}\right)$; $(\mathrm{B}) \% \mathrm{DCPA}$ in filler $\left(\mathrm{X}_{1}\right)$ and \% CCNa $\left(\mathrm{X}_{3}\right)$ on friability $\left(\mathrm{Y}_{4}\right)(\mathrm{n}=3)$ 


\section{Effect of variables on friability}

It is shown from table 2 that formulations F1, F2, F4, F7, F8, F9 and F11 (with $40 \%$ filler) have the friability more than $1 \%$ which did not meet requirement of the British Pharmacopoeia.

Fig. $6 \mathrm{~A}$ shows that when $\%$ filler $\left(\mathrm{X}_{2}\right)$ increased, the friability $\left(\mathrm{Y}_{4}\right)$ significantly decreased. The friability of $A$. crassna tablets was closely related to the hardness [24]. The mixtures of DCPA and SMCC as fillers were found to improve the hardness of $A$. crassna tablets. As a result, these mixtures of filler could decrease the friability of the tablets.

In the case of low level of \% DCPA in filler $\left(\mathrm{X}_{1}\right)$, the friability $\left(\mathrm{Y}_{4}\right)$ increased if \% CCNa $\left(\mathrm{X}_{3}\right)$ increased (fig. 6B). CCNa possesses the porous structure, therefore, the friability increased when \% CCNa $\left(\mathrm{X}_{3}\right)$. A similar finding was previously reported by Oza NA [25].

\section{Optimization of $A$. crassna tablet formulation}

The optimized A. crassna tablet formulation was achieved with $35 \%$ DCPA in filler, $60 \%$ filler and $7 \%$ CCNa. Three replicated batches of the optimized A. crassna tablet formulation were prepared to confirm the validity of the optimization procedure. Weight variation, disintegration time, hardness and friability of the optimized $A$. crassna tablet formulation were found to be at $1.38 \pm 0.42 \%$, $6.29 \pm 0.54 \mathrm{~min}, 85.63 \pm 2.92 \mathrm{~N}$ and $0.41 \pm 0.08 \%$, respectively. Table 4 demonstrates that the observed values were in good agreement with the predicted values $(\mathrm{p}>0.05)$.

Table 4: Comparison of the predicted and observed responses of the optimized $A$. crassna tablet formulation

\begin{tabular}{lllll}
\hline Responses & $\mathbf{Y}_{\mathbf{1}} \mathbf{( \% )}$ & $\mathbf{Y}_{\mathbf{2}} \mathbf{( m i n )}$ & $\mathbf{Y}_{\mathbf{3}} \mathbf{( N )}$ & \multicolumn{1}{l}{$\mathbf{Y}_{\mathbf{4}} \mathbf{( \% )}$} \\
\hline Predicted & 1.15 & 6.34 & 89.10 & 0.491 \\
Observed & $1.38 \pm 0.42$ & $6.29 \pm 0.54$ & $85.63 \pm 2.92$ & $0.41 \pm 0.08$ \\
P-value & 0.400 & 0.853 & 0.054 & 0.208 \\
\hline
\end{tabular}

Values are expressed as mean $\pm \mathrm{SD}(\mathrm{n}=3)$

\section{Analytical method of mangiferin}

A well-resolved HPLC chromatogram of mangiferin in A. crassna tablet sample is shown in fig. 7. The total run time was approximately $40 \mathrm{~min}$ and the retention time of mangiferin was at
$23.6 \mathrm{~min}$. In a concentration range of $60-420 \mu \mathrm{g} / \mathrm{ml}$, a good correlation coefficient was observed between peak areas and concentrations of mangiferin standard solutions $\left(\mathrm{r}^{2}=0.9996\right)$. The recovery values ranged from $99.62 \%$ to $101.90 \%$. These results indicated that the method was reliable and reproducible.

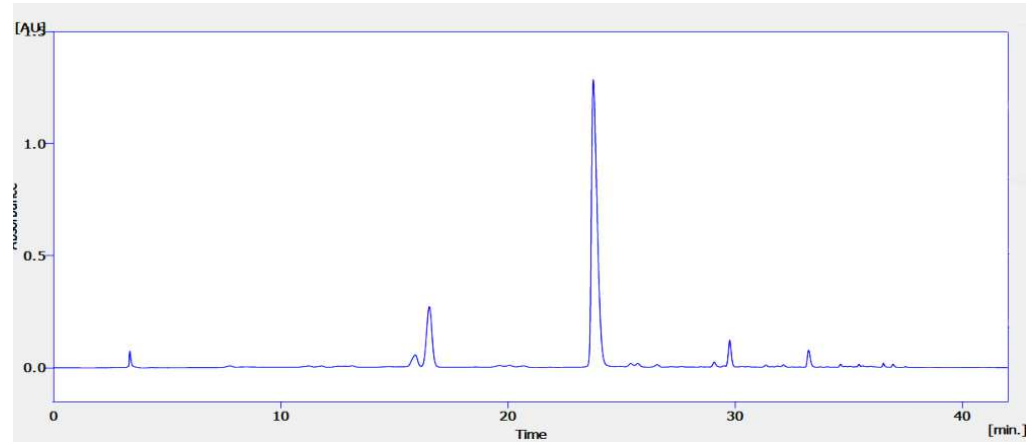

Fig. 7: HPLC chromatogram of mangiferin $\left(\mathrm{R}_{\mathrm{t}}=23.6 \mathrm{~min}\right)$ in the optimized A. crassna tablet

\section{Dissolution study}

The active compound released properties are characterized by disintegration time and dissolution property. Dissolution profiles of the optimized A. crassna tablets in SGF (without enzyme) are shown in fig. 8. More than $97 \%$ of mangiferin could be rapidly released from the optimized A. crassna tablets within 20 min SGF. This observation can be explained by the fact that the optimized A. crassna tablets were disintegrated completely after $6.29 \mathrm{~min}$. As a result, mangiferin could be released completely within $30 \mathrm{~min}$.

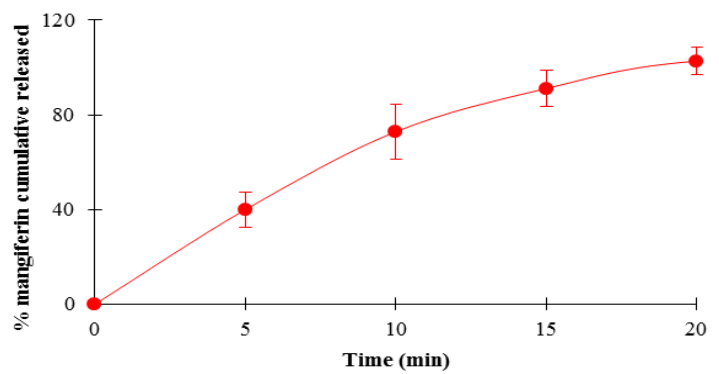

Fig. 8: Dissolution profiles of the optimized $A$. crassna tablets $(\mathrm{n}=6)$

\section{CONCLUSION}

Effects of three independent variables (\% DCPA in filler, \% filler and \% CCNa) on four dependent variables (weight variation, disintegration time, hardness and friability of A. crassna tablet) were investigated. All independent variables were found to possess significantly effects on all dependent variables and the rules were raised up. The optimized A. crassna tablet formulation suggested by the BCPharSoft OPT intelligent software contained 35\% DCPA in filler, $60 \%$ filler and $7 \%$ CCNa. Three replicates of the optimized formulation were prepared and the observed responses were found to be in good agreement with the predicted values which confirmed the optimized $A$. crassna tablet formulation.

\section{AUTHOR CONTRIBUTION}

There are five authors who contribute to this manuscript. The percentages of contribution of Bui Thi Thu Huong, Boonyaphat Monsatta, Nguyen Duc Hanh, Phan Hoang Doan Phuong and Do Quang Duong are $25 \%, 25 \%, 30 \%, 10 \%$, and $10 \%$, respectively.

\section{CONFLICT OF INTERESTS}

All authors declare that this article content has no conflict of interest 


\section{REFERENCES}

1. Feng J, Yang XW, Wang RF. Bio-assay guided isolation and identification of $\alpha$-glucosidase inhibitors from the leaves of Aquilaria sinensis. Phytochemistry 2011;72:242-7.

2. Pranakhon R, Pannangpetch P, Aromdee C. Antihyperglycemic activity of agarwood leaf extracts in STZ-induced diabetic rats and glucose uptake enhancement activity in rat adipocytes. Songklanakarin J Sci Technol 2011;33:405-10.

3. Ito T, Kakino M, Tazawa S, Oyama M, Maruyama H, Araki Y, et al. Identification of phenolic compounds in Aquilaria crassna leaves via liquid chromatography-electrospray ionization mass spectroscopy. Food Sci Technol Res 2012;18:259-62.

4. Kakino M, Izuta H, Ito T, Tsuruma K, Araki Y, Shimazawa M, et al. Agarwood induced laxative effects via acetylcholine receptors on loperamide-induced constipation in mice. Biosci Biotechnol Biochem 2010;74:1550-5.

5. Telang M, Dhulap S, Mandhare A, Hirwani R. Therapeutic and cosmetic applications of mangiferin: a patent review. Expert Opin Ther Pat 2013;23:1561-80.

6. Yoshimi N, Matsunaga K, Katayama M, Yamada Y, Kuno T, Qiao $\mathrm{Z}$, et al. The inhibitory effects of mangiferin, a naturally occurring glucosylxanthone, in bowel carcinogenesis of male F344 rats. Cancer Lett 2001;163:163-70.

7. Kumare MM, Marathe RP, Kawade RM, Ghante MH, Shendarkar GR. Design of fast dissolving tablet of atenolol using novel coprocessed superdisintegrant. Asian J Pharm Clin Res 2013;3:81-5.

8. Thoorens G, Krier F, Leclercq B, Carlin B, Evrard B. Microcrystalline cellulose, a direct compression binder in a quality by design environment-a review. Int J Pharm 2014;473:64-72.

9. Peck GE, Anderson NR, Banker GS. Principles of improved tablet production system design. In: Liebermann HA, Lachman L, Schwartz JB. editors. Pharmaceutical Dosage Forms: Tablets. Lea and Febiger; 1990. p. 1-76.

10. Hentzschel CM, Sakmann A, Leopold CS. Comparison of traditional and novel tableting excipients: physical and compaction properties. Pharm Dev Technol 2012;17:649-53.

11. Ilic I, Govedarica B, Sibanc R, Dreu R, Srcic S. Deformation properties of pharmaceutical excipients determined using an in-die and out-die method. Int J Pharm 2013;446:6-15.

12. Utami D, Nugrahani I, Ibrahim S. Mefenamic acid-nicotinamide co-crystal synthesized by using melt crystallization method and its solubility study. Asian J Pharm Clin Res 2017;10:135-9.

13. British Pharmacopoeia. London, United Kingdom: The General Council of Medical education and Registration of the United Kingdom 2013.

14. Jallo LJ, Dave RN. Explaining electrostatic charging and flow of surface-modified acetaminophen powders as a function of relative humidity through surface energetics. J Pharm Sci 2015;104:2225-32.

15. Bushra R, Shoaib MH, Ali H, Zafar F, Naeem MI, Aslam N, et al. Formulation design and optimization of aceclofenac tablets (100 mg) using central composite design with response surface methodology. Latt Am J Pharm 2014;33:1009-18.

16. Rojas J, Guisao S, Ruge V. Functional assessment of four types of disintegrants and their effect on the spironolactone release properties. AAPS PharmSciTech 2012;13:1054-62.

17. Autamashih $\mathrm{M}$, Isah $\mathrm{AB}$, Allagh TS, Ibrahim MA. Use of anhydrous calcium phosphate and selected binders in the tablet formulation of a deliquescent crude plant extract: Vernonia galamensis (Asteraceae). J Appl Pharm Sci 2011;1:118-22.

18. Tibalinda P, Sempombe J, Shedafa R, Masota N, Pius D, Temu M, et al. Formulation development and optimization of lamivudine $300 \mathrm{mg}$ and tenofovir disopropxil fumarate (TDF) $300 \mathrm{mg}$ FDC tablets by D-optimal mixture design. Heliyon 2016;2:e00207.

19. Tye CK, Sun CC, Amidon GE. Evaluation of the effects of tableting speed on the relationships between compaction pressure, tablet tensile strength, and tablet solid fraction. J Pharm Sci 2005;94:465-72.

20. Vithani K, Maniruzzaman M, Slipper IJ, Mostafa S, Miolane C, Cuppok Y, et al. Sustained release solid lipid matrices processed by hot-melt extrusion (HME). Colloids Surf B 2013;110:403-10.

21. Thoorens G, Krier F, Leclercq B, Carlin B, Evrard B. Microcrystalline cellulose, a direct compression binder in a quality by design environment-a review. Int $\mathrm{J}$ Pharm 2014;473:64-72.

22. Solaiman A, Suliman AS, Shinde S, Naz S, Elkordy AA. Application of general multilevel factorial design with formulation of fast disintegrating tablets containing croscarmellose sodium and Disintequick MCC-25. Int J Pharm 2016;501:87-95.

23. Agrawal A, Dudhedia M, Deng W, Shepard K, Zhong L, Povilaitis $\mathrm{E}$, et al. Development of tablet formulation of amorphous solid dispersions prepared by hot melt extrusion using quality by design approach. AAPS PharmSciTech 2016;17:214-32.

24. Akhtar MS, Malik A, Bashir S, Baig MF, Irshad N. Pharmaceutical evaluation of different brands of levofloxacin tablets (500 mg) available in Pakistan. Int J Curr Pharm Res 2013;5:42-5.

25. Oza NA, Sahu AR, Tripathi SN, Patel PU, Patel LD, Ramkishan A. Formulation development and optimization of fast orodispersible tablets of naratriptan hydrochloride by using factorial design. Int J Res Med 2013;2:48-53.

\section{How to cite this article}

- Bui Thi Thu Huong, Boonyaphat Monsatta, Nguyen Duc Hanh, Phan Hoang Doan Phuong, Do Quang Duong. Study on causeeffect relations and optimization of tablets containing Aquilaria crassna spray-dried extract. Int J Pharm Pharm Sci 2017;9(10):312-317. 